\title{
Institutional Distance and Foreign Subsidiary Performance in Emerging Markets: Moderating Effects of Ownership Strategy and Host-Country Experience
}

\author{
Vikrant Shirodkar ${ }^{1} \cdot$ Palitha Konara $^{2}$
}

Received: 17 February 2015/ Accepted: 11 August 2016/Published online: 19 September 2016

(C) The Author(s) 2016. This article is published with open access at Springerlink.com

\begin{abstract}
Institutional distance has been known to be an important driver of Multinational Enterprises' strategies and performance in host countries. Based on a large panel dataset of 10,562 firms operating in 17 emerging markets and spanning 80 home countries, we re-examine the relationship described by Gaur and $\mathrm{Lu}(\mathrm{J}$ Manage 33(1):84-110, 2007) between regulatory institutional distance and subsidiary performance. We extend this research by (1) examining this relationship in the context of emerging markets, (2) examining the moderating effects of ownership strategy and host-country experience within the context of emerging markets and (3) accounting for a greater variety of institutions by including a large number of home and host countries. We find that institutional distance negatively affects subsidiary performance in emerging markets. Our findings also show that the negative effects of institutional distance on subsidiary performance are lesser for subsidiaries with partial ownership (than for subsidiaries with full ownership) and for subsidiaries with greater host-country experience. We discuss our findings with respect to Gaur and Lu's model, which explores the relationships between these variables in a general context.
\end{abstract}

Keywords Institutional distance $\cdot$ Subsidiary performance $\cdot$ Emerging markets · Multinational enterprises

Vikrant Shirodkar

v.shirodkar@sussex.ac.uk

1 School of Business, Management and Economics, University of Sussex, Brighton, UK

2 The Business School, University of Huddersfield, Huddersfield, UK 


\section{Introduction}

Institutional distance, defined as the difference between the regulatory, cognitive and normative environments (Scott 1995) of the home and host countries of multinational enterprises (MNEs), has been known to be of great importance to international business scholars and managers (Kostova and Zaheer 1999; Xu and Shenkar 2002). Formal (or regulatory) institutional distance increases MNEs' costs associated with learning the 'rules of the game' (North 1990) of new environments. Such liabilities of foreignness (Zaheer 1995) are likely to act as sources of competitive disadvantage to MNEs (Eden and Miller 2004; Miller and Eden 2006). Although, in some industries, the increasing standardisation of practices has been argued to reduce the effect of cross-country institutional differences (Brunsson et al. 2012; Larsen and Manning 2015), institutional distance has been argued to affect various important decisions such as MNEs' choice of location (Xu and Shenkar 2002), entry mode (Schwens et al. 2011), and ownership strategy (Eden and Miller 2004), and it remains an important concept in the analysis of foreign subsidiaries' performance (Gaur and Lu 2007).

Gaur and Lu (2007) argue that although there are disadvantages to operating in countries with different regulatory institutions, distant regulatory environments provide opportunities for institutional arbitrage. For example, in the United States, many MNEs from weaker institutions establish research and development centres to benefit from superior intellectual property protection regimes. However, at high levels of institutional distance, Gaur and $\mathrm{Lu}$ (2007) argue that the scope of such arbitrage becomes narrower, resulting in declining advantages. As regulatory institutional distance increases, subsidiaries face greater 'unfamiliarity and relational hazards' that negatively impact subsidiary performance. In line with this argument, Gaur and Lu (2007) have found an inverted-U-shaped relationship between regulatory institutional distance and foreign subsidiary survival.

In our paper, we first suggest that emerging markets provide unique and important contexts for re-examining the effect of regulatory institutional distance on foreign affiliates' performance. The reason is that in comparison to developed countries, emerging markets have lesser developed, complex and changing formal institutions that pose greater challenges for MNEs from distant institutions (Ionascu et al. 2004; Meyer et al. 2009; Meyer and Nguyen 2005). However, over the past decade, many emerging markets have shown significant development in institutions that minimise bureaucracy in foreign direct investment (FDI), increase transparency in business-government communication, protect intellectual property, and minimise corruption in business transactions (Hoskisson et al. 2013; Luo 2007). Simultaneously, over the past decade, investments by other developing countries in emerging markets have substantially increased, alongside continuing investments by developed countries ${ }^{1}$ (UNCTAD 2015). As emerging markets continue to develop their institutions, MNEs from countries with weaker formal institutions are likely to face greater institutional differences while operating in emerging markets. Examining the link between regulatory institutional distance and the subsidiary performance of

\footnotetext{
1 For instance, South-South FDI between 2009 and 2013 grew by $66 \%$ (i.e., from $\$ 1.7$ trillion in 2009 to $\$ 2.9$ trillion in 2013) and has been speculated to grow at higher rates (UNCTAD 2015).
} 
MNEs within the specific context of emerging markets can therefore add valuable insights to the existing research in this area.

Various factors have been argued to moderate the relationship between institutional distance and MNEs' subsidiary performance. These include entry mode or subsidiary ownership strategies (Gaur and Lu 2007), host-country experience (Carlsson et al. 2005; Delios and Beamish 2001; Gaur and Lu 2007), and MNE's international diversity (Chao and Kumar 2010). Among these, subsidiary ownership strategies and host-country experience have been argued to be the most important. Gaur and Lu (2007) argue that in distant regulatory environments, tightly controlling subsidiary operations via full ownership increases the probability of subsidiary survival. In this context, our second argument is that the moderating effect of ownership strategy can be different in the case of emerging markets. In emerging markets, the importance of embedding in socio-political circles, production networks, and business-government communication channels allows MNEs to gain important intangible resources such as local legitimacy and local reputation (Meyer et al. 2009) and is thus likely to reduce the negative effects of institutional distance. Extending prior research (Gaur and Lu 2007) on the moderating effect of subsidiary ownership in the context of emerging markets can therefore provide new insights. We also suggest that there has been limited prior research on the moderating effect of host-country experience on the institutional distance-subsidiary performance link. Because emerging markets are characterised by a large informal/extra-legal economy and a greater variety of external stakeholders that affect MNEs' operations, we suggest that greater host-country experience is an important aspect of the organisational learning process (Johanson and Vahlne 1977). Accordingly, with greater experience, subsidiaries will be better able to overcome the disadvantages of institutional distance.

Third, we argue that, in general, research on the institutional distance-subsidiary performance relationship can benefit from accounting for firm-level observations from a larger cohort of home and host countries. Recent research highlights that by focusing on a single home (developed) country, the validity of the institutional distance construct can be undermined due to a greater conflation between 'institutional distance' and 'institutional profile effects' (van Hoorn and Maseland 2016), where 'institutional profile' relates to the institutional environment of a particular home or host country where firms are deeply embedded and face distinct opportunities and challenges (Meyer et al. 2009). In their study, Gaur and Lu (2007) consider MNEs from a single (developed) home country, i.e., Japan, and therefore, the variation in institutional distance between Japan and the selected host countries is tantamount to variation in the institutional profile of the host countries. The reason is that because institutional distance is calculated as the difference between home and host countries' institutional profile scores, the use of a single developed home country makes a low institutional profile score for the host country correspond to a high institutional distance with Japan, which makes it impossible to determine whether the observed effects are due to weaker institutions in the host country or due to the dissimilarity of the institutions between the host country and the home country. In response to recent calls (van Hoorn and Maseland 2016) to include a diverse group of countries in institutional distance research, our study also aims to re-evaluate the existing findings on the institutional distance-subsidiary performance relationship by including a wider array of home and host countries. 
Reflecting these limitations in prior research, our paper aims to address the following important questions: (1) What is the effect of formal (regulatory) institutional distance on the performance of MNEs' foreign subsidiaries in emerging markets? and (2) What are the moderating effects of ownership strategy and hostcountry experience on the link between formal institutional distance and subsidiary performance in the context of emerging markets?

We believe that by testing our hypotheses on the linkages among formal institutional distance, ownership strategy, host-country experience and subsidiary performance within the context of emerging markets, we make the following contributions. First, we partially replicate Gaur and Lu (2007) model of the effect of formal institutional distance on the performance of MNEs' foreign subsidiaries and the moderating effect of ownership strategy on this link. By doing so, we contribute to a greater generalisation of the institutional distance-subsidiary performance link within their model by using observations of subsidiaries of MNEs from 80 home countries operating in 17 emerging market countries. As explained above, in contrast to Gaur and Lu (2007) sample, our sample enables us to address an important discussion related to the methodological construct of institutional distance (van Hoorn and Maseland 2016) and to re-evaluate the existing findings on the institutional distance-subsidiary performance relationship. In this process, we follow the guidelines of a 'good enough' replication (Singh et al. 2003), i.e., we employ constructs that are similar to those employed in Gaur and Lu (2007) study, although our measurements of the constructs differ for some variables. Mainly, Gaur and Lu (2007) focus on subsidiary survival, whereas our dependent variable is subsidiary performance (measured by return on equity). Second, based on the extant literature explaining the generic institutional characteristics in emerging markets, we provide new theoretical arguments on the relationship between formal institutional distance and subsidiary performance and on the moderating effect of ownership strategy and host-country experience on this relationship. By doing so, we contribute to prior research on the performance of MNEs' subsidiaries in emerging markets that has examined related issues such as the role of psychic distance (Dikova 2009), business group affiliation (Chacar and Vissa 2005; Khanna and Rivkin 2001), managerial ties and connections (Sheng et al. 2011), embeddedness (Sun et al. 2010), localisation strategies (London and Hart 2004), and parent-subsidiary integration (Luo 2003).

In the following sections, we formulate our hypotheses, describe our data and present our findings from 17 emerging markets. Finally, we discuss our results in relation to Gaur and Lu's (2007) findings in addition to other relevant research, and we conclude our paper by highlighting our contributions and limitations and suggesting important avenues for future research.

\section{Theoretical Background and Hypotheses}

Scholars have emphasised that MNEs are affected by cross-country differences in formal institutions, such as laws and regulations (and the enforcement thereof), and by differences in informal institutions, such as the norms and cognitions arising from cultural differences (Peng et al. 2008, 2009). Institutional theory posits that 
'regulatory' differences (in particular) between countries will increase the liabilities of foreignness to MNEs and will increase the costs of learning the 'rules of the game' (North 1990). Such differences arise from the varieties of business systems among countries that affect the ways in which capital and labour power are organised and controlled, economic exchanges and competing interests are governed, and the nature and policies of the state affect economic activities, the financial system and education and training systems. Qualitatively, institutions also include the dominant beliefs concerning trust, authority and loyalty (Whitley 1992, 1998). Prior literature stresses the need for firms to conform to the nature and quality of local institutions as a precondition for survival and performance (Xu and Shenkar 2002). Because MNEs operate in multiple institutional settings, institutional differences affect subsidiary control mechanisms (Harzing and Sorge 2003), subsidiary staffing strategies (Gaur et al. 2007) and subsidiary work systems and knowledge transfer (Saka 2004).

Within a general context, Gaur and Lu (2007) argue that there is an inverted-U shaped relationship between regulatory institutional distance and subsidiary survival, such that the survival rates at low levels of institutional distance increase but decrease at high levels of institutional distance. The reason is that low levels of institutional distance enable MNEs to gain from institutional arbitrage, i.e., new environmental conditions may act as opportunities for MNEs to exploit their ownership advantages. Although the unfamiliarity of new host institutions necessitates learning and increases costs, these costs are marginal in comparison to the potential benefits, leading to greater subsidiary survival rates. However, at high levels of institutional distance, the costs of learning exceed the accrued benefits, leading to disadvantages in relation to firms from similar institutions (Gaur and $\mathrm{Lu}$ 2007).

\subsection{Institutional Distance and MNEs' Subsidiary Performance in Emerging Markets}

We argue that institutional conditions in emerging markets offer unique challenges to MNEs from distant environments and, therefore, regardless of the level of regulatory institutional distance (Gaur and Lu 2007), MNEs' subsidiaries from similar environments will outperform those from distant environments in emerging markets. The reason is that, first, regulatory institutions in emerging markets are characterised by complexity and continuous change, and these characteristics increase the costs of learning for MNEs, even at low levels of institutional distance, in relation to the potential benefits. For instance, regulations concerning MNEs in emerging markets constantly shift from entry-level restrictions (such as controlling the size, location, timing and partner selection of FDI projects) to restrictions at detailed operational levels (such as controlling for component localisation, export levels, distribution, worker unionisation, environmental protection, and accounting standards) (Luo 2007). In many large emerging markets such as China and India, regulations have shifted from national (i.e., federal) levels to regional (i.e., subnational) levels in recent years. Consequently, MNEs have had to interact with a greater variety of institutional actors (Luo 2007; Meyer and Nguyen 2005). Firms 
from similar institutional settings (such as from other emerging markets) are better equipped to address such complexities and have a clear advantage over subsidiaries from distant environments.

Second, in emerging markets, business systems and governance structures that affect ownership, control, industry collaboration, information gathering and resource access are significantly different from those in developed countries and from those in other developing countries with comparatively greater institutional voids (Jakobsen and Torp 2001; Zhang and Whitley 2013). Firms from developed contexts often depend on reliable information (e.g., about suitable partners, coping with emergencies, addressing ambiguous laws) to devise their strategy, and such information may not be easily available in emerging markets, resulting in negative effects on subsidiary performance (Chacar and Vissa 2005). Furthermore, important local resources such as natural resources, markets, and licences are preferentially accessible to state-owned companies or influential business groups (or chaebols as in Korea) due to the greater embeddedness of such organisations in socio-political networks in many emerging markets (Jakobsen and Torp 2001; Khanna and Palepu 2000b, 2000a). However, despite the heterogeneity among emerging markets, in general, most emerging markets are making improvements in building legitimate business-government interfaces, controlling corruption and reducing bureaucracy and red tape (Hoskisson et al. 2013). Scholars have found that more recently in emerging markets, connections to politicians and managers in other related firms have proven detrimental to foreign subsidiaries' performance (Zhou et al. 2008). Although such developments are advantageous to developed country-based MNEs, they may increase the challenges for firms from other developing countries (with greater institutional voids) that are likely to rely on deeply engrained relational connections with the government to further their business interests. Firms from similar institutional settings are likely to develop better capabilities to align their business strategies with such complex and changing non-market expectations, and they can more easily transfer these capabilities in other emerging markets compared to firms from institutionally distant countries, resulting in competitive advantages. Based on these arguments, we suggest the following:

H1: Ceteris paribus, the performance of MNEs' subsidiaries in emerging markets will decrease with greater formal institutional distance.

\subsection{The Moderating Effect of Ownership Strategy}

Scholars have suggested that the negative effects of regulatory institutional distance can be reduced via partnership with firms that are embedded in the host environment (Delios and Beamish 2001; Delios and Henisz 2003). However, Gaur and Lu (2007) argue that in distant regulatory institutional environments, the choice of a reliable and trustworthy partner is a challenge in itself and the costs of monitoring and coordinating with the partner exceed the benefits. In line with this argument, empirically, they find that Japanese MNEs that tightly controlled their subsidiary operations via full ownership in distant regulatory environments survived longer than joint venture subsidiaries. We suggest that in the context of emerging markets, 
full ownership will increase not only the uncertainty in addressing unfamiliar institutions but also the risk of appropriation of MNEs' assets by the government or other hostile pressure groups (Wright et al. 2005). This is due to the following reasons.

First, scholars have suggested that due to the unavailability of publicly available financial data and other information about indigenous firms in emerging markets, the due diligence costs associated with full ownership strategies (such as acquisitions or greenfield ventures) for firms from distant countries are higher, ultimately negatively affecting subsidiary performance (Peng 2006). In contrast, shared ownership in emerging markets has been argued to be important to firms from institutionally distant countries while accessing critical 'institutional resources' such as legitimacy and reputation (Meyer et al. 2009). Additionally, because important local resources in emerging markets may be restricted to stateowned companies and some influential business groups, partnerships with such organisations have been found to be important drivers of MNEs' subsidiary performance (Khanna and Rivkin 2001; Lin et al. 2009; Peng 2003).

Second, scholars have emphasised the complementarity between the internal assets and capabilities of MNEs (such as technological and management capabilities) and the resources available externally in emerging markets (such as low-cost natural or human resources) (Luo 2001). For this reason, institutional differences can make various external stakeholders in emerging economies perceive MNEs as being exploitative towards local resources in host countries (Child and Tsai 2005). In such a situation, partnerships and alliances increase the level of trust that external institutional actors in emerging economies place in MNEs. We suggest that a high level of trust cannot be developed if MNEs pursue full ownership modes because using these types of modes can be regarded as opportunistic behaviour on the part of MNEs in emerging markets (Schoorman et al. 2007). Scholars have suggested that partial ownership also better allows MNEs' subsidiaries to protect their innovative technology in emerging markets, where the enforcement of intellectual propertyrelated regulations is likely to be weaker (McGaughey et al. 2000). Based on the above arguments, we argue the following:

H2: In emerging markets, the negative effect of formal institutional distance on MNEs' subsidiary performance is reduced with partial subsidiary ownership.

\subsection{The Moderating Effect of Host-Country Experience}

Based on experiential learning theory (Johanson and Vahlne 1977), scholars have suggested that with increased experience in the host country, subsidiaries of foreign firms will learn how to address institutional differences and reduce their liabilities of foreignness, (Fang et al. 2007; Kostova and Zaheer 1999). Greater host-country experience increases the scope for MNEs' subsidiaries to be better equipped to address unfamiliarity and relational hazards in the host country and to develop social and political knowledge, leading to greater legitimacy in the new environment (Gaur and $\mathrm{Lu}$ 2007). With increased experience, subsidiaries of 
foreign firms are also likely to improve their market-specific knowledge and offer differentiated products, access local promotion channels, and accumulate local reputation and product image (Shaver et al. 1997). We suggest that these arguments can be extended to the context of emerging markets.

In this context, first, scholars have suggested that in emerging markets where a variety of external stakeholders often have conflicting interests, greater experience will enable subsidiaries of MNEs from distant institutional environments to identify optimal areas of complementarity and cultivate relationships with the related local actors (Luo and Peng 1999). Such embeddedness, as a potential outcome of hostcountry experience, has been associated with increased subsidiary performance in the context of emerging markets (Sun et al. 2010). For instance, MNEs' subsidiaries entering emerging markets often follow expensive universal codes of conduct such as those prescribed by the International Standards Organisation (ISO) to satisfy stakeholders' expectations (Christmann and Taylor 2001). However, experienced subsidiaries have been found to realise that adapting to locally accepted norms such as complying with the Green Rating Project (in India), sponsoring activities (such as education and healthcare) and engaging with local development organisations allows MNEs to better communicate their practices to local stakeholders and gain legitimacy, which can be associated with improved performance (Rettab et al. 2009).

Second, scholars have suggested that increased host-country experience enables MNEs to effectively adapt their firm-specific intangible assets to the host country institutional setting to ultimately improve subsidiary survival and profitability (Delios and Beamish 2001; Gaur and Lu 2007). Specifically, most emerging markets are characterised by a vast extra-legal economy that is characterised by unregistered assets, tax evasion, and red tape-led corruption; and subsidiaries of MNEs originating from institutionally distant developed countries face the timeconsuming and complex challenge of bridging the extra-legal and legal (or formal) economies to drive positive subsidiary performance in these countries (Prahalad and Hammond 2002). In this context, for instance, after several years of operating in India, the British firm Unilever realised that adapting its product strategies to 'bottom of the pyramid' issues was an important driver of its success in India (London and Hart 2004). Unilever's Indian subsidiary, Hindustan Lever Limited, used a variety of local partners to distribute its products and also sought consumer insights and preferences to develop new products. Ultimately, Unilever was able to generate more than $\$ 1$ billion from the low-income markets in India alone (Ellison et al. 2002). Based on these arguments, we formulate the following hypothesis:

\section{H3: In emerging markets, the negative effect of formal institutional distance on MNEs' subsidiary performance is reduced with greater subsidiary experience in the host country.}

The Fig. 1 describes our theoretical framework. 


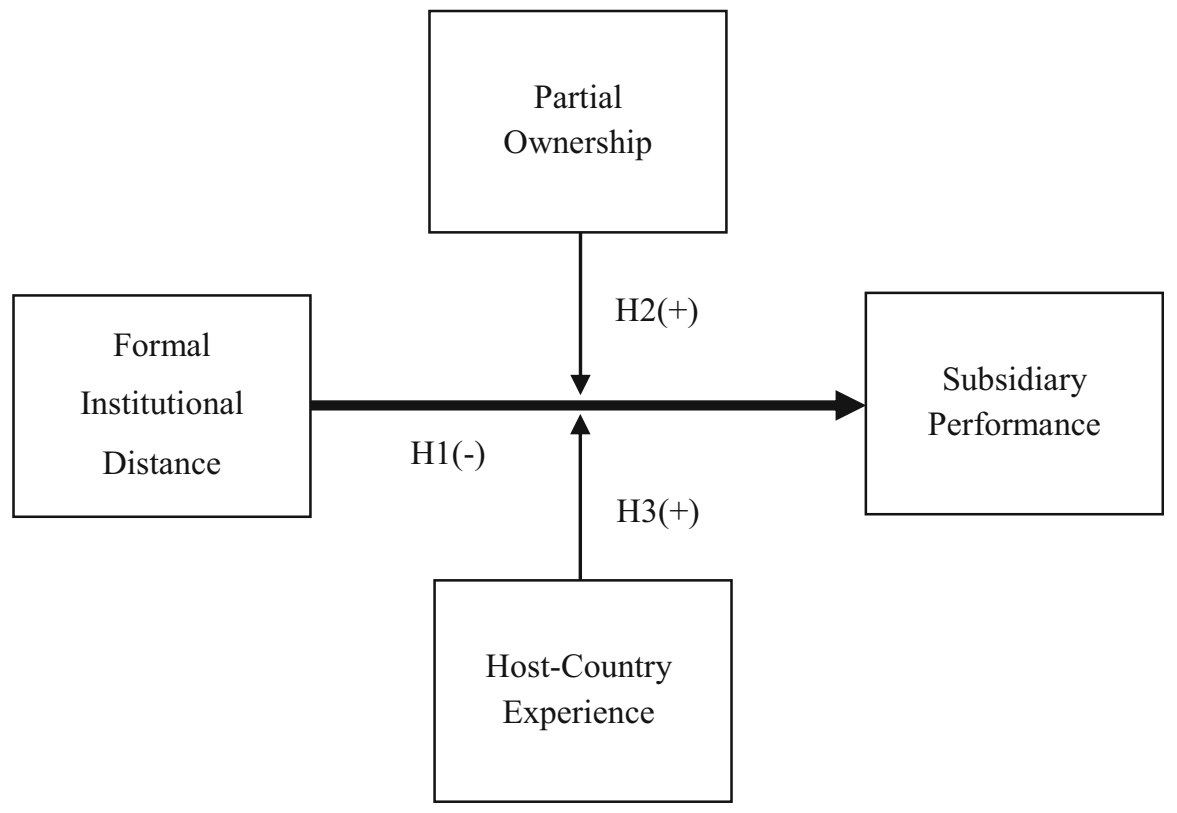

Fig. 1 Theoretical framework

\section{Methodology}

\subsection{Data Collection}

We collected our data from Bureau van Dijk's ORBIS database, which provided us with MNEs' subsidiary-level data over the 9-year period of 2004-2012. Our dataset contains foreign owned firms in the following 17 emerging markets ${ }^{2}-$ Chile, China, Columbia, the Czech Republic, Egypt, Hungary, India, Indonesia, Malaysia, Mexico, Morocco, Peru, the Philippines, Poland, Russia, South Africa and Turkey. Table 1 provides a full list of host and home countries represented by this dataset.

\subsection{Measures}

We measured MNEs' subsidiary performance by return on equity (ROE), which is our dependent variable. ROE has been used as a measure of firm performance in a vast number of studies (e.g., Klarner and Raisch 2012; Zahra et al. 2000).

Our key explanatory variable is the formal institutional distance between the host country of the subsidiary firm and the home country of the parent firm. Various measures of institutional distance are available, such as the Dow index (Dow and Karunaratna 2006), the Kaufmann index (Kaufmann et al. 2007), Hotho's indices (Hotho 2009), and indices from the International Country Risk Guide (Hahn et al.

\footnotetext{
${ }^{2}$ These countries were selected based on the classification of emerging markets by four sources FTSE, Goldman Sachs, Grant Thornton and the International Monetary Fund—and data availability.
} 
Table 1 List of countries used in the study

\begin{tabular}{|c|c|c|}
\hline \multirow{2}{*}{$\begin{array}{l}\text { Host countries (17) } \\
\text { Chile }\end{array}$} & \multicolumn{2}{|l|}{ Home countries $(80)$} \\
\hline & Argentina & Luxembourg \\
\hline China & Australia & Malaysia \\
\hline Colombia & Austria & Malta \\
\hline Czech Republic & Bahrain & Mexico \\
\hline Egypt, Arab Rep. & Belgium & Morocco \\
\hline Hungary & Brazil & Netherlands \\
\hline India & Bulgaria & New Zealand \\
\hline Indonesia & Canada & Norway \\
\hline Malaysia & Chile & Oman \\
\hline Mexico & China & Pakistan \\
\hline Morocco & Colombia & Panama \\
\hline Peru & Costa Rica & Peru \\
\hline Philippines & Croatia & Philippines \\
\hline Poland & Czech Republic & Poland \\
\hline Russian Federation & Denmark & Portugal \\
\hline South Africa & Egypt, Arab Rep. & Qatar \\
\hline \multirow[t]{24}{*}{ Turkey } & Estonia & Romania \\
\hline & Finland & Russian Federation \\
\hline & France & Samoa \\
\hline & Germany & Saudi Arabia \\
\hline & Greece & Serbia \\
\hline & Guatemala & Singapore \\
\hline & Hong Kong Sar, China & Slovak Republic \\
\hline & Hungary & Slovenia \\
\hline & Iceland & South Africa \\
\hline & India & Spain \\
\hline & Indonesia & Sweden \\
\hline & Iran, Islamic Rep. & Switzerland \\
\hline & Ireland & Syrian Arab Republic \\
\hline & Israel & Taiwan, China \\
\hline & Italy & Thailand \\
\hline & Japan & Turkey \\
\hline & Kazakhstan & Ukraine \\
\hline & Kenya & United Arab Emirates \\
\hline & Korea, Dem. Rep. & United Kingdom \\
\hline & Korea, Rep. & United States \\
\hline & Kuwait & Uruguay \\
\hline & Latvia & Uzbekistan \\
\hline & Lebanon & Venezuela, Rb \\
\hline & Lithuania & Vietnam \\
\hline
\end{tabular}


2009), in addition to the World Competitiveness Yearbook used by Gaur and Lu (2007). Because we focus on emerging markets, we operationalise formal institutional distance using Kaufmann's Worldwide Governance Indicators, which have been most popularly used in this context (Dikova 2009; Kolstad and Wiig 2012). For each country, six dimensions of governance, i.e., Voice and Accountability (VA), Political Stability and Absence of Violence (PS), Government Effectiveness (GE), Regulatory Quality (RQ), Rule of Law (RL), and Control of Corruption (CC), are reported in the Worldwide Governance Indicators. For each governance indicator, we calculate the distance between the host country and the home country, and we use these six measures of institutional distance as our main explanatory variables.

We measure ownership strategy (our first moderator) using a dummy variable that takes the value of 1 if the subsidiary is wholly owned (i.e., $100 \%$ ownership) and 0 if the firm is partially owned with at least a $10 \%$ stake. This measure is consistent with Gaur and Lu (2007)'s measure. Finally, we measure host-country experience (our second moderator) using the subsidiary's age in the host country, i.e., the number of years since the firm was incorporated in the given host country. We believe that age is a good measure of host-country experience from a subsidiary perspective for both greenfield and acquisition-type investments because, when an MNE forms a subsidiary by acquiring a local firm, the age of the local firm adds to the subsidiary's host-country experience because the local firm is already embedded in the host country's institutional context. In contrast, when a subsidiary is formed through a greenfield investment, the subsidiary is relatively new to the institutional context.

Guided by previous literature and empirical evidence, we include several control variables. To control for the effect of informal institutional (cultural) distance between the host and the home country, we include two measures, i.e., the language distance (LDIST) and the religious distance (RDIST) between the host country and the home country. Among the firm-level determinants of firm performance, the firm's size and age are the two most widely used demographic characteristics of firms (Klarner and Raisch 2012); therefore, we include firm size and age. The number of patents registered under a firm is often used as a measure of the intangible assets that the firm possesses (Riahi-Belkaoui 2003), and past empirical studies show that patents have a significant positive impact on firm performance (Bloom and van Reenen 2002). Therefore, we also include the number of patents of a firm as a control variable. Existing literature shows that the board and ownership structure can have implications for firm performance (Barth et al. 2005; Core et al. 1999); therefore, we include the number of directors on the board and whether the subsidiary is a publicly listed firm as control variables.

In addition to the firm-level determinants, various factors in the host country can aid or inhibit firm performance. Therefore, we also control for the host country's economic growth rate, infrastructure, level of human capital and income tax rate (Table 2). 
Table 2 Variable description, measurement and sources

\begin{tabular}{|c|c|c|}
\hline Variable & Description/Measurement & Data source \\
\hline ROE & Return on Equity & Bureau van Dijk's ORBIS database \\
\hline LSIZE & Log value of firm's sales & \\
\hline AGE & Firm age & \\
\hline AGEOLDEST & $\begin{array}{l}\text { Age of the oldest firm of all of the firms owned } \\
\text { by the MNE in the focal subsidiary's host } \\
\text { country. }\end{array}$ & \\
\hline NDIR & Number of directors & \\
\hline PATENTS & Number of patents & \\
\hline PUBLIC & $\begin{array}{l}\text { A binary variable that takes the value of one if } \\
\text { the firm is a public firm and zero otherwise. }\end{array}$ & \\
\hline WOS & $\begin{array}{l}\text { A binary variable that takes the value of one if } \\
\text { the firm is a wholly owned subsidiary and zero } \\
\text { if the firm is partially owned with at least a } \\
10 \% \text { stake. }\end{array}$ & \\
\hline VA & Voice and Accountability & Worldwide Governance Indicators \\
\hline PS & Political Stability and Absence of Violence & \\
\hline GE & Government Effectiveness & \\
\hline RQ & Regulatory Quality & \\
\hline RL & Rule of Law & \\
\hline $\mathrm{CC}$ & Control of Corruption & \\
\hline GDPG & GDP growth rate of the host country & World Development Indicators \\
\hline INFRA & $\begin{array}{l}\text { Telephone lines per } 100 \text { people in the host } \\
\text { country }\end{array}$ & \\
\hline TAX & $\begin{array}{l}\text { Total tax rate (\% of commercial profits) in the } \\
\text { host country }\end{array}$ & \\
\hline $\mathrm{HC}$ & $\begin{array}{l}\text { Secondary school enrolment (\% gross) of the } \\
\text { host country }\end{array}$ & \\
\hline \multirow[t]{3}{*}{ LDIST } & $\begin{array}{l}\text { 5-point scale based on the incidence }(\mathrm{p}) \text { of the } \\
\text { home country's dominant language(s) in the } \\
\text { host country }\end{array}$ & Dow and Karunaratna (2004) \\
\hline & $\begin{array}{l}5=\mathrm{p}<1 \% ; 4=1 \% \leq \mathrm{p}<5 \% \\
3=5 \% \leq \mathrm{p}<50 \%\end{array}$ & \\
\hline & $2=50 \% \leq \mathrm{p}<90 \% ; 1=\mathrm{p} \geq 90 \%$ & \\
\hline \multirow[t]{3}{*}{ RDIST } & $\begin{array}{l}\text { 5-point scale based on the incidence (p) of the } \\
\text { home country's dominant religion(s) in the } \\
\text { host country }\end{array}$ & \\
\hline & $\begin{array}{l}5=\mathrm{p}<1 \% ; 4=1 \% \leq \mathrm{p}<5 \% \\
3=5 \% \leq \mathrm{p}<50 \%\end{array}$ & \\
\hline & $2=50 \% \leq \mathrm{p}<90 \% ; 1=\mathrm{p}>90 \%$ & \\
\hline
\end{tabular}

Our baseline specification takes the following form:

$$
\begin{aligned}
\text { ROE }_{\mathrm{it}}= & \beta_{0}+\beta_{1} \text { IDIST }_{\mathrm{jkt}}+\beta_{2} \text { LSIZE }_{\mathrm{it}}+\beta_{3} \mathrm{AGE}_{\mathrm{it}}+\beta_{4} \text { NDIR }_{\mathrm{i}}+\beta_{5} \text { PATENTS }_{\mathrm{i}} \\
& +\beta_{6} \text { PUBLIC }_{\mathrm{i}}+\beta_{7} \mathrm{WOS}_{\mathrm{i}}+\beta_{8} \mathrm{GDPG}_{\mathrm{jt}}+\beta_{9} \text { INFRA }_{\mathrm{jk}}+\beta_{10} \text { TAX }_{\mathrm{jt}} \\
& +\beta_{11} \mathrm{HC}_{\mathrm{jt}}+\beta_{12} \text { LDIST }_{\mathrm{jk}}+\beta_{13} \text { RDIST }_{\mathrm{jk}}+\mu_{\mathrm{j}}+\mu_{\mathrm{k}}+\delta_{\mathrm{t}}+V+\varepsilon_{\mathrm{ijt}}
\end{aligned}
$$


where subscripts $\mathrm{i}, \mathrm{j}, \mathrm{k}$ and $\mathrm{t}$ refer to the firm, host country, home country and observation year, respectively. $\mathrm{ROE}_{\mathrm{it}}$ is the return on equity of firm $\mathrm{i}$ at time $\mathrm{t}$. IDIST $_{\mathrm{jkt}}$ is the institutional distance (formal) between host country $\mathrm{j}$ and home country k. LSIZE $\mathrm{it}_{\mathrm{it}}$ is the log value of the firm's sales. AGE $\mathrm{At}_{\mathrm{it}}, \mathrm{NDIR}_{\mathrm{i}}$ and PATENTS are the firm's age, number of directors, and number of patents, respectively. PUBLIC $_{i}$ and $W_{i}$ are dummy variables; the first variable captures whether the firm is a public firm, and the second variable captures whether the firm is a fully owned subsidiary. GDPG $\mathrm{jt}_{\mathrm{t}}$ is the GDP growth rate of the host country. TEL $\mathrm{T}_{\mathrm{jt}}$ is a measure of infrastructure and is represented by the number of telephone lines per 100 people in the host country. $\mathrm{TAX}_{\mathrm{jt}}$ is the total tax rate (\% of commercial profits) in the host country. $\mathrm{HC}_{\mathrm{jt}}$ is the level of human capital of the host country and is represented by the secondary school enrolment rate (\% gross) of the host country. LDIST is the language distance, measured as the incidence of home country j's dominant language(s) in host country $i$; this indicator is a five-point scale that measures the proportion of the population in the host country that is able to speak the major language(s) of the home country. RDIST is the religious distance, measured as the incidence of the home country's dominant religion(s) in the host country; this indicator is a five-point scale that measures the proportion of the population in the host country that belongs to the same religion(s) of the home country. $\mu_{\mathrm{j}}, \mu_{\mathrm{k}}$ and $\delta_{\mathrm{t}}$ are host country-specific, home country-specific and yearspecific effects, respectively. V captures industry-specific effects. Because unobserved industry-specific effects can affect firm profitability, industry fixed effects are included for a total of 86 sectors. $^{3} \varepsilon_{\mathrm{ijt}}$ is the white noise disturbance term. We expect $\beta_{2}, \beta_{5}, \beta_{8}, \beta_{9}$, and $\beta_{11}$ to be positive and $\beta_{10}, \beta_{12}$ and $\beta_{13}$ to be negative. Given the mixed nature of the existing empirical results, we expect $\beta_{3}, \beta_{4}$ and $\beta_{6}$ to be indecisive a priori.

\section{Results}

The descriptive statistics and correlations are presented in Table 3. It can be observed that the worldwide governance indicators used as measures of institutional distance are highly correlated with each other (as expected), but this is not a problem because we have used each indicator in a separate regression model.

We estimate our specification based on a random effects model (Generalized Least Squares (GLS) estimator) in a four-dimensional panel data framework, where we control for host country-specific, home country-specific, year-specific and industry-specific fixed effects. All estimations are estimated with robust standard errors to control for heteroscedasticity. The estimated results of the base line specification are presented in Table 4.

With regard to the direct effect of formal institutional distance on MNEs' subsidiary performance, models 1.1 through 1.6 show that the estimated coefficients of all six formal institutional distance variables are negative, of which three, i.e.,

\footnotetext{
${ }^{3}$ Industry fixed effects are defined at the two-digit sectoral classification based on the NACE Rev two classification.
} 
Table 3 Descriptive statistics and correlation matrix

\begin{tabular}{|c|c|c|c|c|c|c|c|c|c|c|c|c|c|c|c|c|c|c|c|c|c|c|c|}
\hline \multirow[b]{2}{*}{ Variable } & \multirow[b]{2}{*}{ Obs. } & \multirow[b]{2}{*}{ Mean } & \multirow[b]{2}{*}{$\begin{array}{l}\text { Std. } \\
\text { Dev. }\end{array}$} & \multirow[b]{2}{*}{ Min } & \multirow[b]{2}{*}{ Max } & \multicolumn{18}{|c|}{ Correlation coefficients } \\
\hline & & & & & & 1 & 2 & 3 & 4 & 5 & 6 & 7 & 8 & 9 & 10 & 11 & 12 & 13 & 14 & 15 & 16 & 17 & 18 \\
\hline $1 \overline{\mathrm{ROE}}$ & 40616 & 26.726 & 96.564 & -997.75 & 996.29 & & & & & & & & & & & & & & & & & & \\
\hline $2 \mathrm{CC}$ & 40616 & 1.507 & 0.737 & 0.00 & 3.60 & 0.05 & & & & & & & & & & & & & & & & & \\
\hline $3 \mathrm{GE}$ & 40616 & 1.085 & 0.561 & 0.00 & 2.80 & 0.06 & 0.86 & & & & & & & & & & & & & & & & \\
\hline 4 PS & 40616 & 0.766 & 0.730 & 0.00 & 3.90 & 0.06 & 0.53 & 0.67 & & & & & & & & & & & & & & & \\
\hline $5 \mathrm{RQ}$ & 40616 & 0.851 & 0.622 & 0.00 & 3.10 & 0.07 & 0.77 & 0.85 & 0.75 & & & & & & & & & & & & & & \\
\hline $6 \mathrm{RL}$ & 40616 & 1.222 & 0.685 & 0.00 & 2.90 & 0.08 & 0.85 & 0.92 & 0.74 & 0.89 & & & & & & & & & & & & & \\
\hline $7 \mathrm{VA}$ & 40616 & 0.909 & 0.839 & 0.00 & 3.30 & 0.05 & 0.66 & 0.69 & 0.73 & 0.84 & 0.81 & & & & & & & & & & & & \\
\hline 8 LSIZE & 40616 & 2.095 & 1.662 & 0.00 & 9.04 & 0.02 & 0.14 & 0.16 & 0.18 & 0.17 & 0.15 & 0.18 & & & & & & & & & & & \\
\hline $9 \mathrm{AGE}$ & 40616 & 11.013 & 10.295 & 0.00 & 262.00 & -0.05 & 0.03 & 0.06 & 0.08 & 0.01 & 0.05 & -0.04 & 0.29 & & & & & & & & & & \\
\hline $10 \mathrm{NDIR}$ & 40616 & 2.603 & 3.424 & 0.00 & 43.00 & -0.02 & -0.01 & 0.02 & 0.17 & -0.01 & 0.01 & -0.05 & 0.35 & 0.29 & & & & & & & & & \\
\hline 11 PATENTS & 40616 & 1.070 & 36.519 & 0.002 & 2798.00 & 0.02 & 0.02 & 0.02 & 0.02 & 0.03 & 0.01 & 0.01 & 0.08 & 0.08 & 0.07 & & & & & & & & \\
\hline 12 PUBLIC & 40616 & 0.144 & 0.351 & 0.00 & 1.00 & -0.02 & 0.02 & 0.07 & 0.27 & 0.08 & 0.11 & 0.00 & 0.24 & 0.31 & 0.40 & 0.03 & & & & & & & \\
\hline 13 GDPG & 40616 & 4.304 & 4.351 & -7.82 & 14.20 & 0.02 & 0.14 & 0.20 & 0.22 & 0.32 & 0.23 & 0.36 & 0.14 & -0.01 & -0.04 & 0.03 & 0.01 & & & & & & \\
\hline 14 INFRA & 40616 & 24.736 & 5.669 & 2.63 & 33.86 & 0.07 & 0.12 & 0.08 & -0.06 & 0.07 & 0.14 & 0.19 & -0.14 & -0.27 & -0.24 & -0.05 & -0.44 & -0.03 & & & & & \\
\hline $15 \mathrm{TAX}$ & 40616 & 51.335 & 11.544 & 24.50 & 84.20 & -0.01 & 0.26 & 0.32 & 0.56 & 0.45 & 0.40 & 0.58 & 0.22 & 0.07 & 0.22 & 0.04 & 0.20 & 0.41 & -0.12 & & & & \\
\hline $16 \mathrm{HC}$ & 40616 & 90.981 & 8.825 & 49.59 & 101.89 & -0.04 & -0.40 & -0.45 & -0.61 & -0.66 & -0.53 & -0.70 & -0.22 & -0.03 & -0.05 & -0.06 & -0.23 & -0.40 & 0.16 & -0.66 & & & \\
\hline 17 WOS & 40616 & 0.626 & 0.484 & 0.00 & 1.00 & 0.00 & 0.05 & 0.02 & -0.04 & 0.01 & 0.01 & 0.01 & -0.05 & -0.12 & -0.12 & -0.02 & -0.16 & -0.01 & 0.14 & -0.06 & 0.07 & & \\
\hline 18 LDIST & 40616 & 4.771 & 0.580 & 1.00 & 5.00 & 0.00 & 0.02 & -0.02 & -0.02 & -0.08 & -0.01 & 0.01 & -0.07 & -0.05 & -0.11 & -0.03 & -0.11 & -0.10 & 0.16 & -0.16 & 0.11 & 0.06 & \\
\hline 19 RDIST & 40616 & 2.638 & 0.986 & 1.00 & 5.00 & -0.05 & -0.03 & -0.13 & 0.02 & 0.03 & -0.12 & 0.20 & 0.11 & -0.08 & -0.04 & 0.04 & -0.02 & 0.23 & -0.10 & 0.23 & -0.40 & -0.03 & 0.19 \\
\hline
\end{tabular}

Control of Corruption, Regulatory Quality, and Rule of Law, are significant. With regard to the moderating effect of ownership strategy on the formal institutional distance-subsidiary performance link, we split the sample based on the ownership status (wholly owned subsidiaries vs. partially owned subsidiaries) and repeat the estimations. The results are reported in Table 5.

For the wholly owned subsidiaries (models 2.1 through 2.6), all six institutional distance measures have a negative sign, of which four, i.e., Control of Corruption, Regulatory Quality, Rule of Law and Voice and Accountability, are significant. In contrast, for the partially owned subsidiaries (models 3.1 through 3.6), all six measures of the institutional distance variables are highly insignificant. These results show that institutional distance has a pronounced negative impact on firm performance for wholly owned subsidiaries compared to partially owned subsidiaries.

To observe the moderating effect of host-country experience on the formal institutions distance-subsidiary performance relationship, we interact the institutional distance (IDIST) with the age (AGE) of the firm, and the estimated results are reported in Table 6.

In Table 6, the coefficient of IDIST is negative and also significant in most cases (models 4.1 through 4.6), indicating that institutional distance has a pronounced negative effect on new firms. The interaction term (IDIST * AGE) is positive in all estimations except that with Voice and Accountability (VA), and the interaction term is significant in the first three estimations. These results indicate that the negative effect of institutional distance on firm performance diminishes with greater host-country experience.

With regard to the effect of the control variables regarding informal institutional distance, LDIST and RDIST are negative and significant in most of the estimations. With regard to the firm-level control variables, the coefficient of LSIZE has the expected positive sign and is highly significant. PATENTS has the expected positive sign and is significant in all cases except for partially owned subsidiaries. This result 
Table 4 Institutional distance and subsidiary performance (total sample)

\begin{tabular}{|c|c|c|c|c|c|c|}
\hline & 1.1 & 1.2 & 1.3 & 1.4 & 1.5 & 1.6 \\
\hline $\mathrm{CC}$ & $\begin{array}{r}-5.832 * \\
(3.435)\end{array}$ & & & & & \\
\hline GE & & $\begin{array}{r}-0.985 \\
(3.493)\end{array}$ & & & & \\
\hline PS & & & $\begin{array}{r}-0.994 \\
(2.089)\end{array}$ & & & \\
\hline RQ & & & & $\begin{array}{c}-8.439 * * \\
(3.304)\end{array}$ & & \\
\hline RL & & & & & $\begin{array}{r}-5.881^{*} \\
(3.379)\end{array}$ & \\
\hline VA & & & & & & $\begin{array}{r}-5.751 \\
(3.931)\end{array}$ \\
\hline LSIZE & $\begin{array}{r}9.184 * * * \\
(0.655)\end{array}$ & $\begin{array}{r}9.167 * * * \\
(0.654)\end{array}$ & $\begin{array}{r}9.168 * * * \\
(0.654)\end{array}$ & $\begin{array}{r}9.175 * * * \\
(0.654)\end{array}$ & $\begin{array}{r}9.166^{* * * *} \\
(0.655)\end{array}$ & $\begin{array}{r}9.162 * * * \\
(0.654)\end{array}$ \\
\hline AGE & $\begin{array}{c}-0.680 * * * \\
(0.0881)\end{array}$ & $\begin{array}{c}-0.677 * * * \\
(0.0880)\end{array}$ & $\begin{array}{c}-0.677 * * * \\
(0.0881)\end{array}$ & $\begin{array}{c}-0.681 * * * \\
(0.0882)\end{array}$ & $\begin{array}{c}-0.680 * * * \\
(0.0881)\end{array}$ & $\begin{array}{c}-0.679 * * * \\
(0.0881)\end{array}$ \\
\hline NDIR & $\begin{array}{c}-1.471 * * * \\
(0.327)\end{array}$ & $\begin{array}{c}-1.462 * * * \\
(0.327)\end{array}$ & $\begin{array}{c}-1.465^{* * * *} \\
(0.327)\end{array}$ & $\begin{array}{c}-1.468 * * * \\
(0.327)\end{array}$ & $\begin{array}{c}-1.474 * * * \\
(0.327)\end{array}$ & $\begin{array}{c}-1.457 * * * \\
(0.326)\end{array}$ \\
\hline PATENTS & $\begin{array}{r}0.0785 * * * \\
(0.0205)\end{array}$ & $\begin{array}{r}0.0784 * * * \\
(0.0205)\end{array}$ & $\begin{array}{r}0.0784 * * * \\
(0.0206)\end{array}$ & $\begin{array}{r}0.0784 * * * \\
(0.0204)\end{array}$ & $\begin{array}{r}0.0785 * * * \\
(0.0205)\end{array}$ & $\begin{array}{r}0.0783 * * * \\
(0.0206)\end{array}$ \\
\hline PUBLIC & $\begin{array}{c}-19.12^{* * * *} \\
(3.529)\end{array}$ & $\begin{array}{c}-19.15^{* * *} \\
(3.527)\end{array}$ & $\begin{array}{c}-19.11 * * * \\
(3.530)\end{array}$ & $\begin{array}{c}-19.19 * * * \\
(3.526)\end{array}$ & $\begin{array}{c}-19.14 * * * \\
(3.528)\end{array}$ & $\begin{array}{c}-19.15^{* * * *} \\
(3.528)\end{array}$ \\
\hline GDPG & $\begin{array}{r}1.304 * * * \\
(0.262)\end{array}$ & $\begin{array}{r}1.371 * * * \\
(0.260)\end{array}$ & $\begin{array}{r}1.360 * * * \\
(0.261)\end{array}$ & $\begin{array}{r}1.324 * * * \\
(0.258)\end{array}$ & $\begin{array}{r}1.392 * * * \\
(0.255)\end{array}$ & $\begin{array}{r}1.371 * * * \\
(0.256)\end{array}$ \\
\hline INFRA & $\begin{array}{l}0.697 * * \\
(0.283)\end{array}$ & $\begin{array}{l}0.615^{* * *} \\
\quad(0.281)\end{array}$ & $\begin{array}{l}0.618 * * \\
(0.280)\end{array}$ & $\begin{array}{r}0.707 * * \\
(0.281)\end{array}$ & $\begin{array}{l}0.726^{* * *} \\
(0.286)\end{array}$ & $\begin{array}{r}0.723 * * \\
(0.293)\end{array}$ \\
\hline TAX & $\begin{array}{c}-0.431 * * \\
(0.191)\end{array}$ & $\begin{array}{c}-0.420^{* *} \\
(0.190)\end{array}$ & $\begin{array}{c}-0.419 * * \\
(0.191)\end{array}$ & $\begin{array}{c}-0.492 * * \\
(0.194)\end{array}$ & $\begin{array}{c}-0.415^{* *} * \\
(0.190)\end{array}$ & $\begin{array}{c}-0.452^{* * *} \\
(0.193)\end{array}$ \\
\hline $\mathrm{HC}$ & $\begin{array}{l}0.152 \\
\quad(0.232)\end{array}$ & $\begin{array}{l}0.0707 \\
\quad(0.226)\end{array}$ & $\begin{array}{l}0.0727 \\
\quad(0.228)\end{array}$ & $\begin{array}{l}0.0271 \\
\quad(0.227)\end{array}$ & $\begin{array}{l}0.108 \\
\quad(0.227)\end{array}$ & $\begin{array}{l}0.0676 \\
(0.226)\end{array}$ \\
\hline WOS & $\begin{array}{c}-4.053 * * \\
(1.760)\end{array}$ & $\begin{array}{c}-4.060 * * \\
(1.760)\end{array}$ & $\begin{array}{c}-4.055^{* *} \\
(1.761)\end{array}$ & $\begin{array}{c}-4.014 * * \\
(1.760)\end{array}$ & $\begin{array}{c}-4.029 * * \\
(1.760)\end{array}$ & $\begin{array}{c}-4.108 * * \\
(1.760)\end{array}$ \\
\hline LDIST & $\begin{array}{c}-4.344 * * \\
(2.088)\end{array}$ & $\begin{array}{c}-4.827 * * \\
(2.081)\end{array}$ & $\begin{array}{c}-4.694 * * \\
(2.111)\end{array}$ & $\begin{array}{r}-4.012 * \\
(2.081)\end{array}$ & $\begin{array}{c}-4.162 * * \\
(2.097)\end{array}$ & $\begin{array}{c}-4.314 * * \\
(2.118)\end{array}$ \\
\hline RDIST & $\begin{array}{r}-2.738^{*} \\
(1.594)\end{array}$ & $\begin{array}{r}-2.692^{*} \\
(1.592)\end{array}$ & $\begin{array}{r}-2.696^{*} \\
(1.595)\end{array}$ & $\begin{array}{r}-2.628 * \\
(1.596)\end{array}$ & $\begin{array}{r}-2.750^{*} \\
(1.597)\end{array}$ & $\begin{array}{r}-2.395 \\
(1.599)\end{array}$ \\
\hline Constant & $\begin{array}{l}45.61 \\
\quad(54.43)\end{array}$ & $\begin{array}{l}49.66 \\
\quad(54.64)\end{array}$ & $\begin{array}{l}49.10 \\
\quad(54.55)\end{array}$ & $\begin{array}{l}65.38 \\
\quad(55.18)\end{array}$ & $\begin{array}{l}49.47 \\
\quad(54.55)\end{array}$ & $\begin{array}{l}61.83 \\
\quad(55.67)\end{array}$ \\
\hline $\mathrm{N}$ & 40,616 & 40,616 & 40,616 & 40,616 & 40,616 & 40,616 \\
\hline $\mathrm{R} 2$ & 0.0452 & 0.0450 & 0.0450 & 0.0453 & 0.0452 & 0.0452 \\
\hline
\end{tabular}

Robust standard errors in parentheses $* * * \mathrm{p}<0.01$, ** $\mathrm{p}<0.05, * \mathrm{p}<0.1$

For reasons of brevity, country-specific fixed effects, year-specific fixed effects and industry-specific fixed effects are not reported 


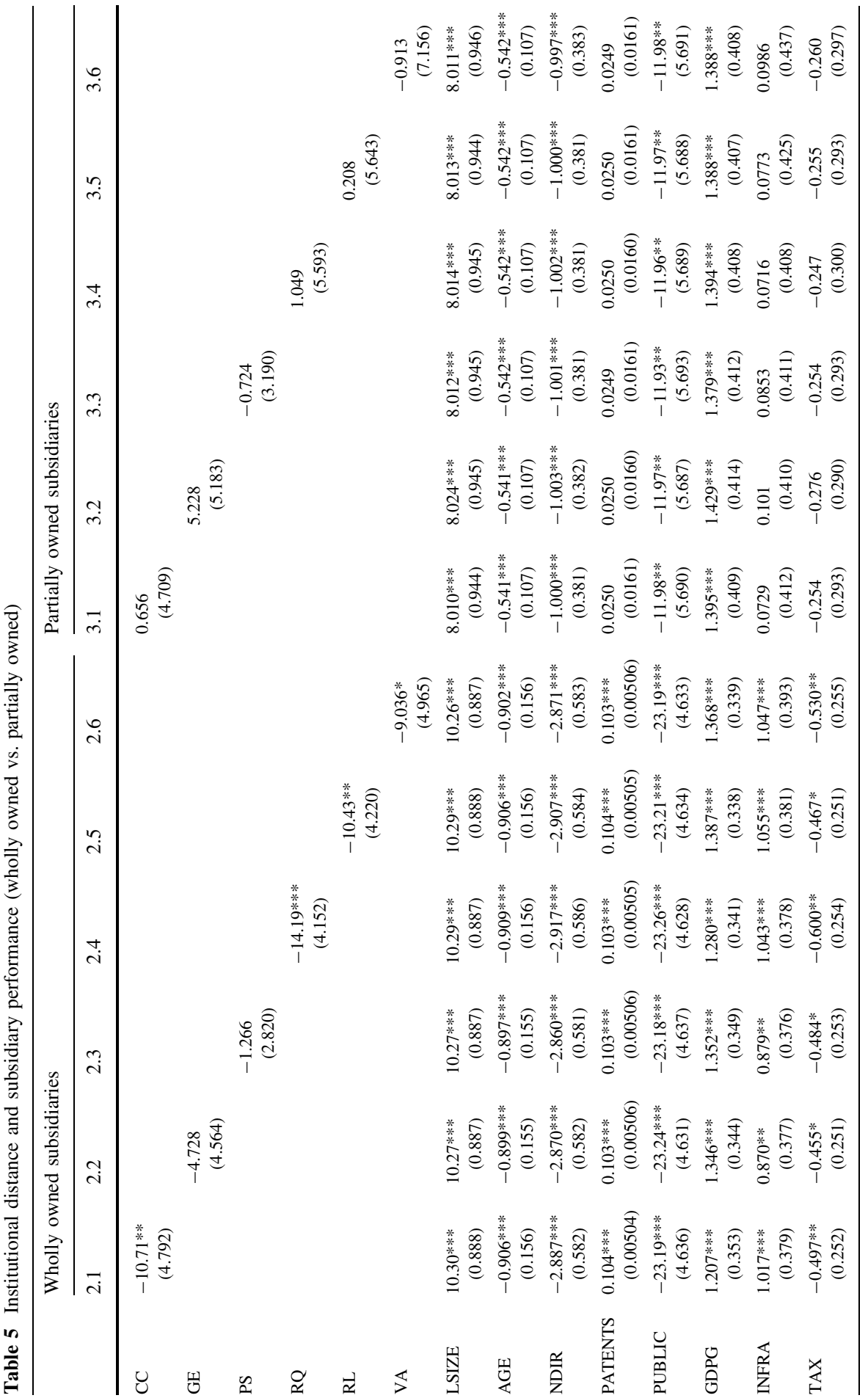




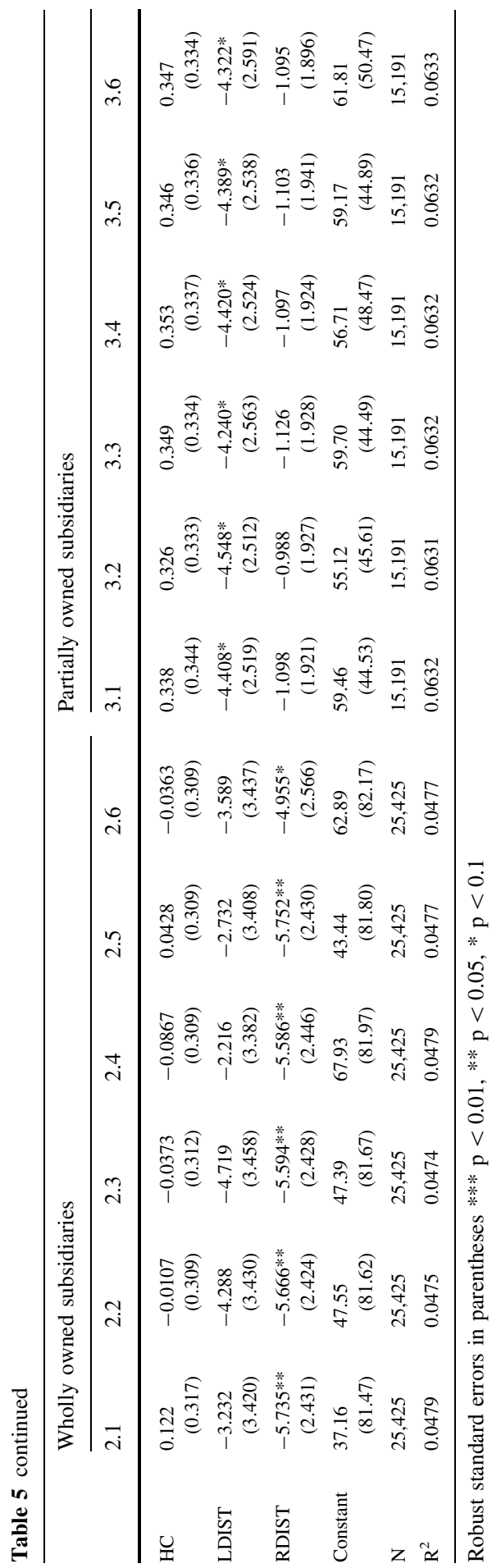


Table 6 Institutional distance and subsidiary performance (moderating effect of host-country experience)

\begin{tabular}{|c|c|c|c|c|c|c|}
\hline & $\begin{array}{l}\text { IDIST }=C C \\
4.1\end{array}$ & $\begin{array}{l}\text { IDIST }=\mathrm{GE} \\
4.2\end{array}$ & $\begin{array}{l}\text { IDIST }=\text { PS } \\
4.3\end{array}$ & $\begin{array}{l}\text { IDIST }=\text { RQ } \\
4.4\end{array}$ & $\begin{array}{l}\text { IDIST }=\text { RL } \\
4.5\end{array}$ & $\begin{array}{l}\text { IDIST }=\text { VA } \\
4.6\end{array}$ \\
\hline IDIST & $\begin{array}{c}-7.981 * * \\
(3.784)\end{array}$ & $\begin{array}{c}-3.956 \\
(3.894)\end{array}$ & $\begin{array}{c}-4.927 * * \\
(2.489)\end{array}$ & $\begin{array}{c}-10.30 * * * \\
(3.719)\end{array}$ & $\begin{array}{c}-7.136 * * \\
(3.601)\end{array}$ & $\begin{array}{r}-5.310 \\
(4.157)\end{array}$ \\
\hline $\begin{array}{l}\text { IDIST * } \\
\text { AGE }\end{array}$ & $\begin{array}{l}0.215^{*} \\
\quad(0.122)\end{array}$ & $\begin{array}{l}0.346^{* * *} \\
(0.147)\end{array}$ & $\begin{array}{l}0.355 * * * \\
(0.0971)\end{array}$ & $\begin{array}{l}0.190 \\
\quad(0.136)\end{array}$ & $\begin{array}{l}0.151 \\
\quad(0.124)\end{array}$ & $\begin{array}{r}-0.0509 \\
(0.112)\end{array}$ \\
\hline AGE & $\begin{array}{c}-1.037 * * * \\
(0.217)\end{array}$ & $\begin{array}{c}-1.119 * * * \\
(0.209)\end{array}$ & $\begin{array}{c}-1.057 * * * \\
(0.137)\end{array}$ & $\begin{array}{c}-0.878 * * * \\
(0.159)\end{array}$ & $\begin{array}{c}-0.905 * * * \\
(0.201)\end{array}$ & $\begin{array}{c}-0.628 * * * \\
(0.134)\end{array}$ \\
\hline LSIZE & $\begin{array}{r}9.177 * * * \\
(0.655)\end{array}$ & $\begin{array}{r}9.167 * * * \\
(0.655)\end{array}$ & $\begin{array}{r}9.201 * * * \\
(0.655)\end{array}$ & $\begin{array}{r}9.173^{* * * *} \\
(0.654)\end{array}$ & $\begin{array}{r}9.163 * * * \\
(0.655)\end{array}$ & $\begin{array}{r}9.166 * * * \\
(0.654)\end{array}$ \\
\hline NDIR & $\begin{array}{c}-1.479 * * * \\
(0.327)\end{array}$ & $\begin{array}{c}-1.483 * * * \\
(0.326)\end{array}$ & $\begin{array}{c}-1.603 * * * \\
(0.329)\end{array}$ & $\begin{array}{c}-1.489 * * * \\
(0.327)\end{array}$ & $\begin{array}{c}-1.480 * * * \\
(0.326)\end{array}$ & $\begin{array}{c}-1.456 * * * \\
(0.326)\end{array}$ \\
\hline PATENTS & $\begin{array}{r}0.0773 * * * \\
(0.0212)\end{array}$ & $\begin{array}{r}0.0771 * * * \\
(0.0214)\end{array}$ & $\begin{array}{r}0.0762 * * * \\
(0.0218)\end{array}$ & $\begin{array}{r}0.0763 * * * \\
(0.0218)\end{array}$ & $\begin{array}{r}0.0784 * * * \\
(0.0206)\end{array}$ & $\begin{array}{r}0.0783 * * * \\
(0.0207)\end{array}$ \\
\hline PUBLIC & $\begin{array}{c}-18.86^{* * * *} \\
(3.546)\end{array}$ & $\begin{array}{c}-18.88 * * * \\
(3.539)\end{array}$ & $\begin{array}{c}-18.47 * * * \\
(3.537)\end{array}$ & $\begin{array}{c}-18.97 * * * \\
(3.551)\end{array}$ & $\begin{array}{c}-18.92 * * * \\
(3.550)\end{array}$ & $\begin{array}{c}-19.19 * * * \\
(3.535)\end{array}$ \\
\hline GDPG & $\begin{array}{r}1.306 * * * \\
(0.262)\end{array}$ & $\begin{array}{r}1.382 * * * \\
(0.260)\end{array}$ & $\begin{array}{r}1.357 * * * \\
(0.261)\end{array}$ & $\begin{array}{r}1.339 * * * \\
(0.257)\end{array}$ & $\begin{array}{r}1.396 * * * \\
(0.255)\end{array}$ & $\begin{array}{r}1.365 * * * \\
(0.256)\end{array}$ \\
\hline INFRA & $\begin{array}{l}0.667 * * \\
(0.282)\end{array}$ & $\begin{array}{l}0.596^{* *} \\
(0.280)\end{array}$ & $\begin{array}{l}0.538 * \\
\quad(0.281)\end{array}$ & $\begin{array}{l}0.700 * * \\
(0.280)\end{array}$ & $\begin{array}{l}0.697 * * \\
(0.286)\end{array}$ & $\begin{array}{l}0.727 * * \\
(0.292)\end{array}$ \\
\hline TAX & $\begin{array}{c}-0.419 * * \\
(0.191)\end{array}$ & $\begin{array}{c}-0.390 * * \\
(0.190)\end{array}$ & $\begin{array}{c}-0.377 * * \\
(0.192)\end{array}$ & $\begin{array}{c}-0.468 * * \\
(0.194)\end{array}$ & $\begin{array}{c}-0.400 * * \\
(0.191)\end{array}$ & $\begin{array}{c}-0.461 * * \\
(0.194)\end{array}$ \\
\hline $\mathrm{HC}$ & $\begin{array}{l}0.120 \\
\quad(0.232)\end{array}$ & $\begin{array}{l}0.0556 \\
\quad(0.226)\end{array}$ & $\begin{array}{l}0.0265 \\
\quad(0.229)\end{array}$ & $\begin{array}{r}0.00996 \\
\quad(0.227)\end{array}$ & $\begin{array}{l}0.0890 \\
\quad(0.228)\end{array}$ & $\begin{array}{l}0.0787 \\
\quad(0.228)\end{array}$ \\
\hline WOS & $\begin{array}{c}-4.128 * * \\
(1.762)\end{array}$ & $\begin{array}{c}-4.155^{* *} \\
(1.761)\end{array}$ & $\begin{array}{c}-4.183 * * \\
(1.759)\end{array}$ & $\begin{array}{c}-4.040 * * \\
(1.761)\end{array}$ & $\begin{array}{c}-4.093 * * \\
(1.763)\end{array}$ & $\begin{array}{c}-4.100 * * \\
(1.760)\end{array}$ \\
\hline LDIST & $\begin{array}{c}-4.384 * * \\
(2.087)\end{array}$ & $\begin{array}{c}-4.962 * * \\
(2.082)\end{array}$ & $\begin{array}{c}-4.951 * * \\
(2.111)\end{array}$ & $\begin{array}{r}-3.970 * \\
(2.078)\end{array}$ & $\begin{array}{c}-4.268 * * \\
(2.103)\end{array}$ & $\begin{array}{c}-4.288 * * \\
(2.119)\end{array}$ \\
\hline RDIST & $\begin{array}{r}-2.776^{*} \\
(1.593)\end{array}$ & $\begin{array}{r}-2.728 * \\
(1.592)\end{array}$ & $\begin{array}{r}-2.771 * \\
(1.596)\end{array}$ & $\begin{array}{r}-2.634^{*} \\
(1.596)\end{array}$ & $\begin{array}{r}-2.758 * \\
(1.596)\end{array}$ & $\begin{array}{r}-2.405 \\
(1.600)\end{array}$ \\
\hline Constant & $\begin{array}{l}50.97 \\
\quad(54.43)\end{array}$ & $\begin{array}{l}54.90 \\
\quad(54.65)\end{array}$ & $\begin{array}{l}57.78 \\
\quad(54.65)\end{array}$ & $\begin{array}{l}69.03 \\
\quad(55.23)\end{array}$ & $\begin{array}{l}53.20 \\
\quad(54.60)\end{array}$ & $\begin{array}{l}60.31 \\
\quad(55.85)\end{array}$ \\
\hline $\mathrm{N}$ & 40,616 & 40,616 & 40,616 & 40,616 & 40,616 & 40,616 \\
\hline $\mathrm{R} 2$ & 0.0453 & 0.0454 & 0.0457 & 0.0455 & 0.0454 & 0.0452 \\
\hline
\end{tabular}

Robust standard errors in parentheses, *** $\mathrm{p}<0.01$, ** $\mathrm{p}<0.05, * \mathrm{p}<0.1$

For brevity, country-specific, year-specific and industry-specific fixed effects are not reported

is in line with the notion that full ownership enables parent firms to optimally utilise their intangible resources, ultimately having a positive impact on subsidiary performance. Interestingly, AGE has a negative coefficient (and is highly significant), which shows that the firm's performance deteriorates with age. NDIR and PUBLIC have negative and significant coefficients. This finding could be due to the larger overheads associated with maintaining a large board and being a public company. WOS is negative and significant in all estimations, which is in contrast with the finding by Gaur and Lu (2007), who argue and find evidence for a positive 
performance effect of wholly owned subsidiaries. Our result is in line with our argument that full ownership may not be the best strategy in the context of emerging markets. Turning to the country-level control variables, GDPG and INFRA are positive and significant, implying that the economic growth rate and the level of infrastructure in the host country have a positive effect on firm performance. TAX is negative and significant, confirming that the tax rate in the host country can have a negative effect on subsidiary profits. Although the level of human capital in the host country (HC) has the expected positive sign in most cases, it is not significant at the $10 \%$ level.

Given that Gaur and Lu (2007) examine the curvilinear effects of institutional distance on MNEs' subsidiary performance, we also test for this possibility in the context of emerging markets (see Table 7). However, we find that the curvilinear effects are insignificant.

To test the robustness of our results, we also repeat the regressions with different cut-off points (i.e., 90 and $95 \%$ ) to differentiate partial and full ownership (see Table 8). We find that doing so did not significantly change our original results. We also test for an alternative measure of host-country experience. Because an MNE may have multiple subsidiaries in the host country ${ }^{4}$ and it is possible that an MNE can gain experience in the host country's institutional context through its other sibling subsidiaries in the same host country, in our alternative measure, $A G E O L D E S T$, we calculate the host-country experience based on the age of the oldest firm out of all of the firms owned by the MNE in the focal subsidiary's host country. We then repeat the regressions using this variable (see Table 9). We do not find any significant differences from our original findings. MNEs are often accused of using transfer pricing to shift profits to tax havens to minimise their overall tax liability. Because we use an accounting-based measure of performance (i.e., ROE), it is important to address this issue. Based on 11 lists of tax havens compiled by Chavagneux et al. (2010), Haberly and Wójcik (2015) have produced a list of countries that have 75, 50 and $25 \%$ levels of agreement on tax haven definition. We use the list of countries with a $75 \%$ level of agreement, i.e., countries that appear in at least $75 \%$ of the lists (i.e., 9 out of the 11 lists), and then repeat our regressions after excluding these countries from our sample. ${ }^{5}$ All of our results remain intact. We believe that this exercise will minimise any bias introduced by the issue of transfer pricing.

\section{Discussion and Conclusion}

This study was inspired by the increasing development of formal institutions in emerging markets and the implications thereof for existing theoretical and empirical insights on the institutional distance-subsidiary performance link. In regard to the direct effect of formal institutional distance on subsidiary performance, our findings

\footnotetext{
${ }^{4}$ Our sample consists of a total of 5647 unique parent firm-host country pairs, and in 1133 of those pairs, the parent firm has more than one subsidiary in the host country.

5 For reasons of brevity, we do not report these results; however, they are available upon request.
} 


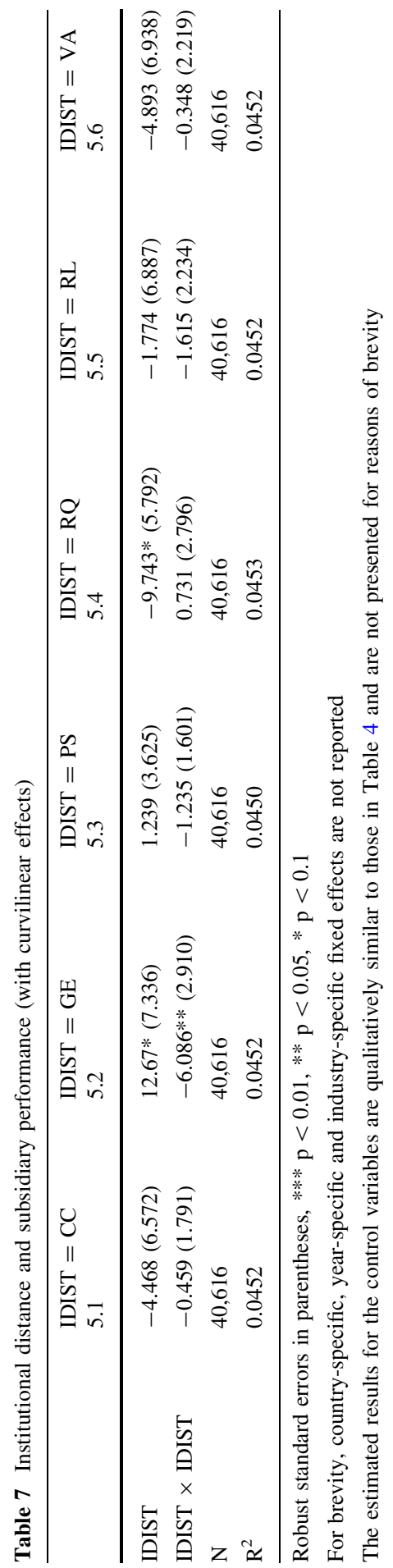




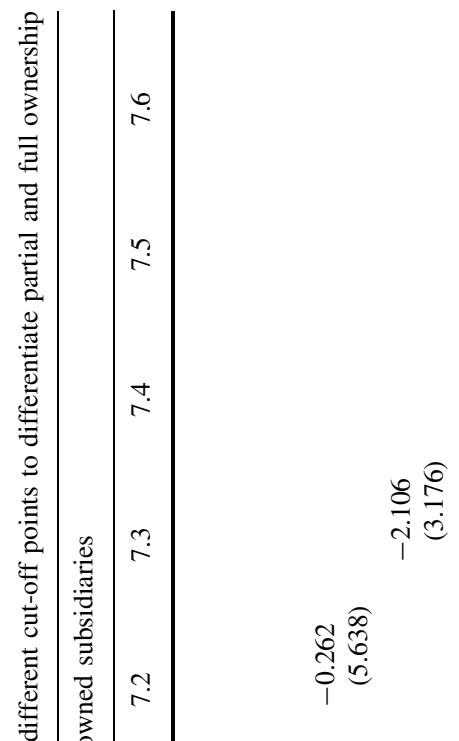

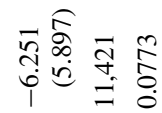

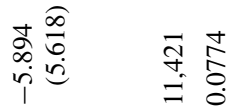

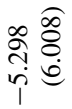

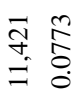

$\frac{6}{2}$

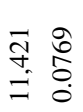

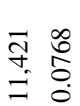<smiles>C1=C[As]=[As]1</smiles>

吾

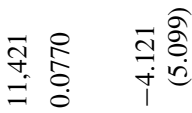

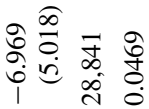

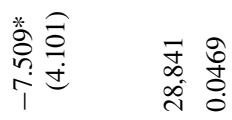

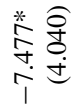

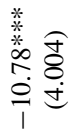

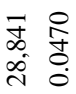

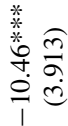

$=\frac{\sqrt{2}}{0} \underset{0}{i}$

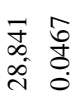

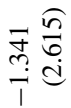

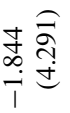

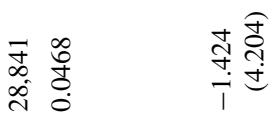

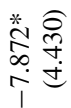

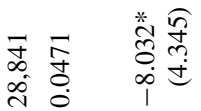

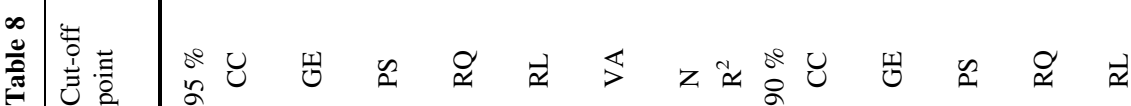




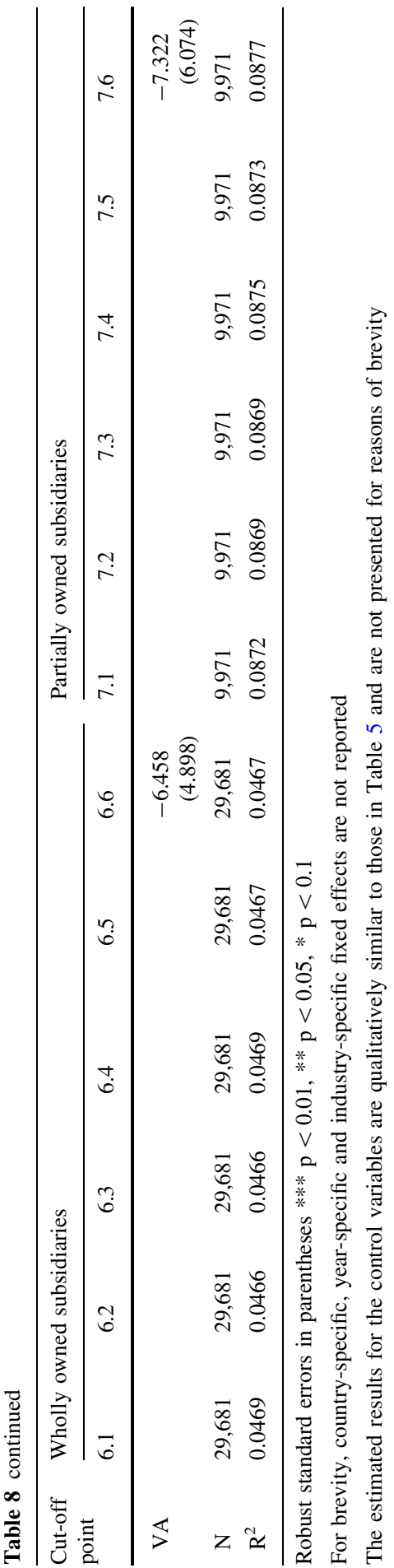




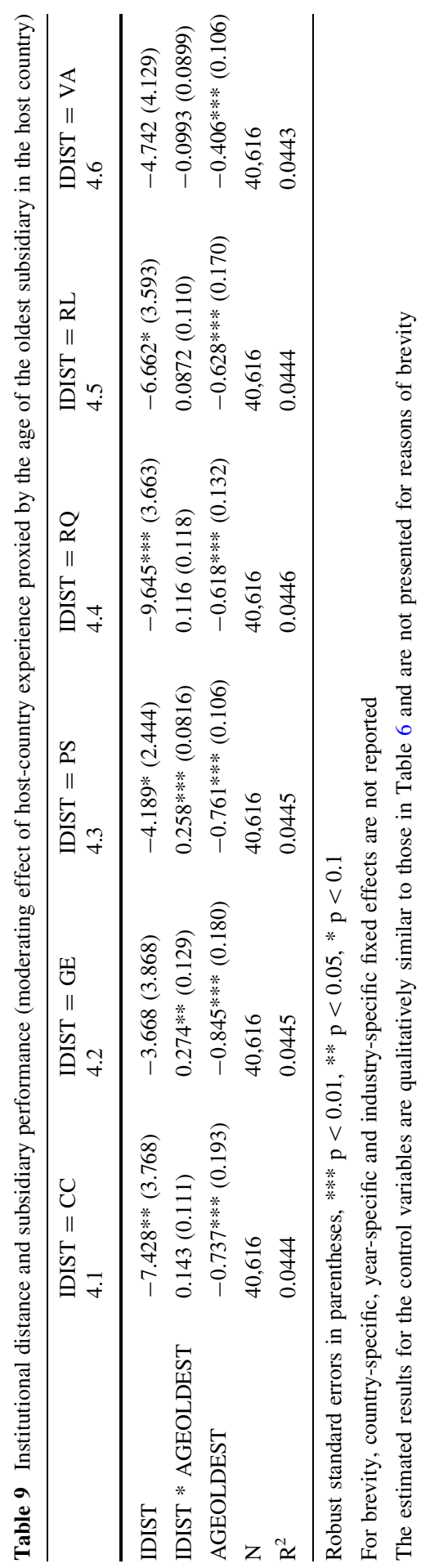


from 17 emerging markets provide support for our hypothesis 1, in which we argue that greater institutional distance will have a negative impact on subsidiary performance. Our results (Table 4) show that formal institutional distance is significantly negatively associated with MNEs' subsidiary performance in emerging markets. Therefore, we suggest that emerging markets constitute a setting where the differences arising from MNEs' home- and host-country regulatory environments increase the 'liabilities of foreignness' (Kostova 1999; Kostova et al. 2008; Kostova and Zaheer 1999) for firms from both less-developed and developed countries and have negative implications for the performance of MNEs' subsidiaries operating in these markets. Our results provide alternative insights in relation to prior studies that have argued and found evidence for the curvilinear effects of regulative institutional distance in a general international context (i.e., not limited to emerging economy contexts) (Gaur and Lu 2007) and positive effects of regulative institutional distance in specific emerging market regions such as Central and Eastern Europe (e.g., Dikova 2009). Therefore, our study suggests that emerging markets constitute a unique context where the potential opportunities arising from differences in institutions do not directly result in a competitive advantage for firms from distant environments.

Our study also examines the moderating effects of ownership strategy and hostcountry experience on the relationship between formal institutional distance and subsidiary performance in emerging markets. With regard to the moderating effect of ownership strategy on the formal institutional distance-subsidiary performance link, our findings show that the negative effect of institutional distance on subsidiary performance is higher for firms with full ownership in emerging markets and that the negative effect is insignificant for firms with partial ownership, thus supporting our hypothesis 2 . Our finding on this moderating effect in the context of emerging markets contrasts with prior studies conducted in a general context where the wholly owned option has been found to improve subsidiary survival in institutionally distant contexts (e.g., Gaur and Lu 2007). We thus provide alternative explanations in relation to these findings obtained in a general context (i.e., not specific to emerging markets $)^{6}$ by examining the context of emerging markets.

Finally, regarding the moderating effect of host-country experience, our empirical results support our hypothesis 3, in which we argue that with greater host-country experience, subsidiaries will be able to mitigate the negative effect of institutional distance on performance. Table 6 shows that institutional distance has a pronounced negative effect on new firms and that this negative effect decreases with the increase in subsidiary age. Although previous studies (not limited to the context of emerging markets) have emphasised that host-country experience is likely to reduce the 'liabilities of foreignness' associated with institutional distance (Delios and Beamish 2001; Gaur and Lu 2007; Luo and Peng 1999), we are the first to empirically test this possibility and to provide supporting evidence that host-country experience will improve foreign subsidiaries' performance in institutionally distant environments. We assert that with greater learning and experience, foreign subsidiaries from distant environments will be able to gain legitimacy advantages

\footnotetext{
${ }^{6}$ In contrast to our study, Gaur and $\mathrm{Lu}$ (2007) examine subsidiary survival, and their sample is limited to one home country, i.e., Japan.
} 
by embedding within social and political frameworks in host countries, eventually resulting in improved subsidiary performance outcomes.

Among our control variables, an interesting observation is that our informal institutional distance variables (LDIST and RDIST) are consistently and significantly negatively associated with subsidiary performance (see Tables 4, 5 and 6). Our finding supports previously found arguments on the negative association between psychic distance and subsidiary performance in single emerging market countries such as China (Carlsson et al. 2005). Our finding also contrasts with prior studies that have argued that cultural and psychic distance is a positive driver of MNEs' foreign affiliates' performance in other contexts, such as in the global retail industry (Evans and Mavondo 2002; Evans et al. 2008) and among foreign subsidiaries in specific emerging market regions such as Central and Eastern Europe (Dikova 2009). Thus, our study, conducted in 17 emerging markets, provides alternative evidence in relation to the previously found explanations of why greater cultural distances are positively associated with subsidiary performance, and it contributes to the on-going debate on the psychic distance paradox (O'Grady and Lane 1996).

Despite these important contributions, we believe that our study has some limitations that can be addressed in future research. One important limitation of this study is that we focus on only the objective aspects of subsidiary performance (i.e., the return on equity) and do not include subjective factors such as improvements in product development and managerial perceptions of critical success factors being achieved. However, there is a consensus that the objective aspects reflect the subjective aspects (Lumpkin and Dess 2001). Nevertheless, we suggest that future research can include survey methods to combine both subjective and objective aspects of subsidiary performance. Second, due to data limitations, we focus on only the macro aspects of subsidiary strategy, and we are not able to account for the micro aspects of organisational behaviour that drive firm performance. Research on the microfoundations of firms' dynamic capabilities-i.e., processes, routines, paths, organizational structures, decision rules, and disciplines-has argued that these are important drivers of the performance of firms (Felin et al. 2012; Foss and Lindenberg 2013; Teece 2007), including MNEs (e.g., Augier and Teece 2007; Foss and Pedersen 2004). We suggest that future research can combine quantitative methods with qualitative evidence to provide deeper insights into the micro aspects of subsidiary strategy and performance. Finally, the measure of formal institutional distance that we used in our study has been argued to capture only the effectiveness of institutions that are 'external' to the firm (such as the effectiveness of the government in controlling corruption, protecting property rights etc.) and to ignore the institutional factors that are 'internal' to the firm, such as differences between business systems (Whitley 1998; Zhang and Whitley 2013). Although scholars have been developing new measures of institutional distance based on Whitley's work (e.g., Hotho 2009; Hotho and Pedersen 2012), to date, these measures have focussed on the European context and have not been extended to include several emerging market countries. Future research on emerging markets can therefore contribute to developing these new measures of institutional comparison, which can potentially lead to new insights into the relationship between institutional distance and 
subsidiary performance. Despite these limitations, we suggest that this study enhances our understanding of the link between institutional distance and subsidiary performance and addresses the growing need for understanding the intersection among institutional distance, host-country experience, ownership strategy and subsidiary performance.

Open Access This article is distributed under the terms of the Creative Commons Attribution 4.0 International License (http://creativecommons.org/licenses/by/4.0/), which permits unrestricted use, distribution, and reproduction in any medium, provided you give appropriate credit to the original author(s) and the source, provide a link to the Creative Commons license, and indicate if changes were made.

\section{References}

Augier, M., \& Teece, D. J. (2007). Dynamic capabilities and multinational enterprise: penrosean insights and omissions. Management International Review, 47(2), 175-192.

Barth, E., Gulbrandsen, T., \& Schønea, P. (2005). Family ownership and productivity: the role of ownermanagement. Journal of Corporate Finance, 11(1), 107-127.

Bloom, N., \& van Reenen, J. (2002). Patents, real options and firm performance. The Economic Journal, 112(478), C97-C116.

Brunsson, N., Rasche, A., \& Seidl, D. (2012). The dynamics of standardization: three perspectives on standards in organization studies. Organization Studies, 33(5-6), 613-632.

Carlsson, J., Nordegren, A., \& Sjöholm, F. (2005). International experience and the performance of Scandinavian firms in China. International Business Review, 14(1), 21-40.

Chacar, A., \& Vissa, B. (2005). Are emerging economies less efficient? Performance persistence and the impact of business group affiliation. Strategic Management Journal, 26(10), 933-946.

Chao, M. C.-H., \& Kumar, V. (2010). The impact of institutional distance on the international diversityperformance relationship. Journal of World Business, 45(1), 93-103.

Chavagneux, C., Murphy, R., \& Palan, R. (2010). Tax havens: How globalization really works. London: Cornell University Press.

Child, J., \& Tsai, T. (2005). The Dynamic Between Firms' Environmental Strategies and Institutional Constraints in Emerging Economies: evidence from China and Taiwan. Journal of Management Studies, 42(1), 95-125.

Christmann, P., \& Taylor, G. (2001). Globalization and the environment: determinants of firm selfregulation in China. Journal of International Business Studies, 32(3), 439-458.

Core, J. E., Holthausen, R. W., \& Larcker, D. F. (1999). Corporate governance, chief executive officer compensation, and firm performance. Journal of Financial Economics, 51(3), 371-406.

Delios, A., \& Beamish, P. W. (2001). Survival and profitability: the roles of experience and intangible assets in foreign subsidiary performance. Academy of Management Journal, 44(5), 1028-1038.

Delios, A., \& Henisz, W. J. (2003). Political hazards, experience, and sequential entry strategies: the international expansion of Japanese firms, 1980-1998. Strategic Management Journal, 24(11), 1153-1164.

Dikova, D. (2009). Performance of foreign subsidiaries: does psychic distance matter? International Business Review, 18(1), 38-49.

Dow, D., \& Karunaratna, A. (2006). Developing a multidimensional instrument to measure psychic distance stimuli. Journal of International Business Studies, 37(5), 578-602.

Eden, L., \& Miller, S. R. (2004). Distance matters: liability of foreignness, institutional distance and ownership strategy. Advances in International Management, 16(4), 187-221.

Ellison, B., Moller, D., \& Rodriguez, M. (2002). Hindustan Lever re-invents the wheel. IESE, University of Navarra: Barcelona, Spain (unpublished).

Evans, J., \& Mavondo, F. T. (2002). Psychic Distance and Organizational Performance: an Empirical Examination of International Retailing Operations. Journal of International Business Studies, 33(3), 515-532.

Evans, J., Mavondo, F. T., \& Bridson, K. (2008). Psychic distance: antecedents, retail strategy implications, and performance outcomes. Journal of International Marketing, 16(2), 32-63. 
Fang, Y., Wade, M., Delios, A., \& Beamish, P. W. (2007). International diversification, subsidiary performance, and the mobility of knowledge resources. Strategic Management Journal, 28(10), 1053-1064.

Felin, T., Foss, N. J., Heimeriks, K. H., \& Madsen, T. L. (2012). Microfoundations of routines and capabilities: individuals, processes, and structure. Journal of Management Studies, 49(8), 1351-1374.

Foss, N. J., \& Lindenberg, S. (2013). Microfoundations for strategy: a goal-framing perspective on the drivers of value creation. The Academy of Management Perspectives, 27(2), 85-102.

Foss, N. J., \& Pedersen, T. (2004). Organizing knowledge processes in the multinational corporation: an introduction. Journal of International Business Studies, 35(5), 340-349.

Gaur, A. S., Delios, A., \& Singh, K. (2007). Institutional environments, staffing strategies, and subsidiary performance. Journal of Management, 33(4), 611-636.

Gaur, A. S., \& Lu, J. W. (2007). Ownership strategies and survival of foreign subsidiaries: impacts of institutional distance and experience. Journal of Management, 33(1), 84-110.

Haberly, D., \& Wójcik, D. (2015). Tax havens and the production of offshore FDI: an empirical analysis. Journal of Economic Geography, 15(1), 75-101.

Hahn, E. D., Doh, J. P., \& Bunyaratavej, K. (2009). The evolution of risk in information systems offshoring: the impact of home country risk, firm learning, and competitive dynamics. MIS Quarterly, 33(3), 597-616.

Harzing, A.-W., \& Sorge, A. (2003). The relative impact of country of origin and universal contingencies on internationalization strategies and corporate control in multinational enterprises: worldwide and European perspectives. Organization Studies, 24(2), 187-214.

Hoskisson, R. E., Wright, M., Filatotchev, I., \& Peng, M. W. (2013). Emerging multinationals from MidRange economies: the influence of institutions and factor markets. Journal of Management Studies, 50(7), 1295-1321.

Hotho, J. J. (2009). A measure of comparative institutional distance (p. 14). Center for Strategic Management and Globalization: Copenhagen Business School.

Hotho, J. J., \& Pedersen, T. (2012). Beyond the 'Rules of the Game': Three institutional approaches and how they matter for international business. Handbook of Institutional Approaches to International Business (pp. 236-273). Cheltenham: Edward Elgar Publishing, Incorporated

Ionascu, D., Meyer, K. E., \& Estrin, S. (2004). Institutional distance and international business strategies in emerging economies, William Davidson Institute Working Paper \#728.

Jakobsen, G., \& Torp, J. E. (2001). Understanding Business Systems in Developing Countries: Sage.

Johanson, J., \& Vahlne, J.-E. (1977). The internationalization process of the firm-a model of knowledge development and increasing foreign market commitments. Journal of International Business Studies, 8(1), 23-32.

Kaufmann, D., Kraay, A., \& Mastruzzi, M. (2007). The Worldwide Governance Indicators Project: Answering the critics (Vol. 4149): World Bank Publications.

Khanna, T., \& Palepu, K. (2000a). The future of business groups in emerging markets: long-run evidence from Chile. Academy of Management Journal, 43(3), 268-285.

Khanna, T., \& Palepu, K. (2000b). Is group affiliation profitable in emerging markets? An analysis of diversified Indian business groups. The Journal of Finance, 55(2), 867-891.

Khanna, T., \& Rivkin, J. W. (2001). Estimating the performance effects of business groups in emerging markets. Strategic Management Journal, 22(1), 45-74.

Klarner, P., \& Raisch, S. (2012). Move to the beat-Rhythms of change and firm performance. Academy of Management Journal, 56(1), 160-184.

Kolstad, I., \& Wiig, A. (2012). What determines Chinese outward FDI? Journal of World Business, 47(1), 26-34.

Kostova, T. (1999). Transnational transfer of strategic organizational practices: a contextual perspective. Academy of Management Review, 24(2), 308-324.

Kostova, T., Roth, K., \& Dacin, M. T. (2008). Institutional theory in the study of multinational corporations: a critique and new directions. Academy of Management Review, 33(4), 994-1006.

Kostova, T., \& Zaheer, S. (1999). Organizational legitimacy under conditions of complexity: the case of the multinational enterprise. Academy of Management Review, 24(1), 64-81.

Larsen, M. M., \& Manning, S. (2015). Does Institutional Distance still matter? Industry standards and global sourcing location choices. In Academy of International Business: Best Paper proceedings. 
Lin, Z. J., Peng, M. W., Yang, H., \& Sun, S. L. (2009). How do networks and learning drive M\&As? An institutional comparison between China and the United States. Strategic Management Journal, 30(10), 1113-1132.

London, T., \& Hart, S. L. (2004). Reinventing strategies for emerging markets: beyond the transnational model. Journal of International Business Studies, 35(5), 350-370.

Lumpkin, G. T., \& Dess, G. G. (2001). Linking two dimensions of entrepreneurial orientation to firm performance: the moderating role of environment and industry life cycle. Journal of Business Venturing, 16(5), 429-451.

Luo, Y. (2001). Toward a cooperative view of MNC-host government relations: building blocks and performance implications. Journal of International Business Studies, 32(3), 401-419.

Luo, Y. (2003). Market-seeking MNEs in an emerging market: how parent-subsidiary links shape overseas success. Journal of International Business Studies, 34(3), 290-309.

Luo, Y. (2007). From foreign investors to strategic insiders: shifting parameters, prescriptions and paradigms for MNCs in China. Journal of World Business, 42(1), 14-34.

Luo, Y., \& Peng, M. W. (1999). Learning to compete in a transition economy: Experience, environment, and performance. Journal of International Business Studies, 30(2), 269-295.

McGaughey, S. L., Liesch, P. W., \& Poulson, D. (2000). An unconventional approach to intellectual property protection: the case of an Australian firm transferring shipbuilding technologies to China. Journal of World Business, 35(1), 1-20.

Meyer, K. E., Estrin, S., Bhaumik, S. K., \& Peng, M. W. (2009). Institutions, resources, and entry strategies in emerging economies. Strategic Management Journal, 30(1), 61-80.

Meyer, K. E., \& Nguyen, H. V. (2005). Foreign Investment Strategies and Sub-national Institutions in Emerging Markets: evidence from Vietnam*. Journal of Management Studies, 42(1), 63-93.

Miller, S. R., \& Eden, L. (2006). Local density and foreign subsidiary performance. Academy of Management Journal, 49(2), 341-355.

North, D. C. (1990). Institutions, institutional change and economic performance. Cambridge university press.

O'Grady, S., \& Lane, H. W. (1996). The psychic distance paradox. Journal of International Business Studies, 27(2), 309-333.

Peng, M. W. (2003). Institutional transitions and strategic choices. Academy of Management Review, 28(2), 275-296.

Peng, M. W. (2006). Making M\&A fly in China. Harvard Business Review, 84(3), 26-27.

Peng, M. W., Li, S. S., Pinkham, B., \& Chen, H. (2009). The institution-based view as a third leg for a strategy tripod. Academy of Management Perspectives, 23(3), 63-81.

Peng, M. W., Wang, D. Y. L., \& Jiang, Y. (2008). An institution-based view of international business strategy: a focus on emerging economies. Journal of International Business Studies, 39(5), 920-936.

Prahalad, C. K., \& Hammond, A. (2002). Serving the world's poor, profitably. Harvard Business Review, $80(9), 48-59$.

Rettab, B., Brik, A. B., \& Mellahi, K. (2009). A study of management perceptions of the impact of corporate social responsibility on organisational performance in emerging economies: the case of Dubai. Journal of Business Ethics, 89(3), 371-390.

Riahi-Belkaoui, A. (2003). Intellectual capital and firm performance of US multinational firms: a study of the resource-based and stakeholder views. Journal of Intellectual Capital, 4(2), 215-226.

Saka, A. (2004). The cross-national diffusion of work systems: translation of Japanese operations in the UK. Organization Studies, 25(2), 209-228.

Schoorman, F. D., Mayer, R. C., \& Davis, J. H. (2007). An integrative model of organizational trust: past, present, and future. Academy of Management Review, 32(2), 344-354.

Schwens, C., Eiche, J., \& Kabst, R. (2011). The moderating impact of informal institutional distance and formal institutional risk on SME entry mode choice. Journal of Management Studies, 48(2), 330-351.

Scott, W. R. (1995). Institutions and organizations. Thousand Oaks: Sage Publications.

Shaver, J. M., Mitchell, W., \& Yeung, B. (1997). The effect of own-firm and other-firm experience on foreign direct investment survival in the United States, 1987-92. Strategic Management Journal, 18(10), 811-824.

Sheng, S., Zhou, K. Z., \& Li, J. J. (2011). The effects of business and political ties on firm performance: evidence from China. Journal of Marketing, 75(1), 1-15.

Singh, K., Ang, S. H., \& Leong, S. M. (2003). Increasing replication for knowledge accumulation in strategy research. Journal of Management, 29(4), 533-549. 
Sun, P., Mellahi, K., \& Thun, E. (2010). The dynamic value of MNE political embeddedness: the case of the Chinese automobile industry. Journal of International Business Studies, 41(7), 1161-1182.

Teece, D. J. (2007). Explicating dynamic capabilities: the nature and microfoundations of (sustainable) enterprise performance. Strategic Management Journal, 28(13), 1319-1350.

UNCTAD. (2015). World Investment Report 2015: Reforming international investment governance. Geneva: United Nations.

van Hoorn, A., \& Maseland, R. (2016). How institutions matter for international business: institutional distance effects vs institutional profile effects. Journal of International Business Studies, 47(3), 374-381.

Whitley, R. (1992). Societies, firms and markets: the social structuring of business systems (pp. 5-45). European Business Systems: Firms and Markets in their National Contexts.

Whitley, R. (1998). Internationalization and varieties of capitalism: the limited effects of cross-national coordination of economic activities on the nature of business systems. Review of International Political Economy, 5(3), 445-481.

Wright, M. W., Filatotchev, I., Hoskisson, R. E., \& Peng, M. W. (2005). Strategy Research in Emerging Economies: challenging the Conventional Wisdom. Journal of Management Studies, 42(1), 1-33.

$\mathrm{Xu}$, D., \& Shenkar, O. (2002). Note: institutional distance and the multinational enterprise. Academy of Management Review, 27(4), 608-618.

Zaheer, S. (1995). Overcoming the liability of foreignness. Academy of Management Journal, 38(2), 341-363.

Zahra, S. A., Ireland, R. D., \& Hitt, M. A. (2000). International expansion by new venture firms: international diversity, mode of market entry, technological learning, and performance. Academy of Management Journal, 43(5), 925-950.

Zhang, X., \& Whitley, R. (2013). Changing macro-structural varieties of East Asian capitalism. SocioEconomic Review, 11(2), 301-336.

Zhou, K. Z., Poppo, L., \& Yang, Z. (2008). Relational ties or customized contracts? An examination of alternative governance choices in China. Journal of International Business Studies, 39(3), 526-534. 